\title{
Element Distribution in the Silicomanganese Production Process
}

\author{
YAN MA, ELMIRA MOOSAVI-KHOONSARI, IDA T. KERO, \\ and GABRIELLA M. TRANELL
}

A pilot scale, silicomanganese alloy production campaign was performed in a $440 \mathrm{kVA}$, single phase electric furnace in order to establish an overview of the minor- and trace element contents in process input raw materials and their distribution in the resulting primary and secondary products. Samples of the in-going raw materials (manganese ore, coke, quartzite, and high carbon ferromanganese slag) and the out-going products (silicomanganese alloy, silicomanganese slag, and dust) were analyzed by inductively coupled plasma mass spectrometry. The distribution of 51 elements between the product phases was discussed in terms of their boiling temperatures, Gibbs energies of oxidation and activity coefficients of elements in the metal. A thermochemical simulation using the thermochemical software FactSage 7.1 was also carried out in order to model element phase distribution between the alloy, slag, and dust/gas. The correlation between the model and experimental element concentrations in the silicomanganese slag and dust is fair for most elements. However, in the metal phase, fewer elements show good correlation between modeled results and measured experimental concentrations. The discrepancy could be explained by a lack of accurate thermodynamic descriptions for several minor species in the database.

https://doi.org/10.1007/s11663-018-1358-9

(C) The Author(s) 2018

\section{INTRODUCTION}

Ferromanganese (FeMn) and silicomanganese (SiMn) alloys are key additions in modern steel production. Both high carbon ferromanganese (HC FeMn) and standard SiMn alloys are produced by carbothermic reduction of oxidic raw materials in Submerged Arc Furnaces (SAF). Standard SiMn with 18 to $20 \mathrm{wt}$ pet $\mathrm{Si}$ and $70 \mathrm{wt}$ pet $\mathrm{Mn}$ is typically produced from raw materials such as MnO-rich slag from the $\mathrm{HC}$ FeMn production process, manganese ores, quartz or quartzite, (Fe)Si-remelts or off-grade qualities of $(\mathrm{Fe}) \mathrm{Si}$, and coke. ${ }^{[1]} \mathrm{A}$ process temperature of $1600{ }^{\circ} \mathrm{C}$ to $1650{ }^{\circ} \mathrm{C}$ is necessary to obtain metal with sufficiently high content of $\mathrm{Si}$ and a discard slag with low $\mathrm{MnO}$ content. ${ }^{[1]}$ The production process, as well as inand out-going (product) material flows are illustrated in Figure 1, adapted from Reference 2.

YAN MA, ELMIRA MOOSAVI-KHOONSARI, and GABRIELLA M. TRANELL are with the Norwegian University of Science and Technology (NTNU), Alfred Getz vei 2, 7491 Trondheim, Norway. Contact e-mail: yan.ma@ntnu.no IDA T. KERO is with the SINTEF Materials and Chemistry, Alfred Getz vei 2, 7465 Trondheim, Norway. Manuscript submitted December 2, 2017.

Article published online July 25, 2018.
When a closed SAF is used in manganese alloy production, the furnace off-gas contains a significant amount of dust from fuming reactions in the furnace, and must be scrubbed. A series of wet scrubbers are typically used, yielding a sludge containing the dust and water. The off-gas may be further cleaned before it escapes the plant (in for example, mercury removal units).

The reduction reactions of main elements in the SiMn production process are as follows ${ }^{[1]}$ :

$$
\begin{gathered}
\mathrm{MnO}(1, \mathrm{~s})+\mathrm{C}(\mathrm{s})=\mathrm{Mn}(1)+\mathrm{CO}(\mathrm{g}) \\
\mathrm{SiO}_{2}(1)+2 \mathrm{C}(\mathrm{s})=\mathrm{Si}(1)+2 \mathrm{CO}(\mathrm{g})
\end{gathered}
$$

In addition to these reactions, reduction, melting, and fuming reactions for a large range of minor and trace elements will take place concurrently in the formation of metal, slag, and gas/dust product phases.

$\mathrm{The} \mathrm{FeSi} / \mathrm{Si}$ production process has some similarities with the SiMn process, and the elemental distribution in the Si furnace has been studied by Myrhaug and Tveit. ${ }^{[3]}$ Myrhaug and Tveit established that the behavior of different elements in the $\mathrm{FeSi} / \mathrm{Si}$ production process depends on several factors: furnace temperature; stability of oxides and carbides of the elements; volatility of the elements/their compounds; solubility of elements in liquid metal; and by which type of raw materials they enter the process. They developed a so-called 


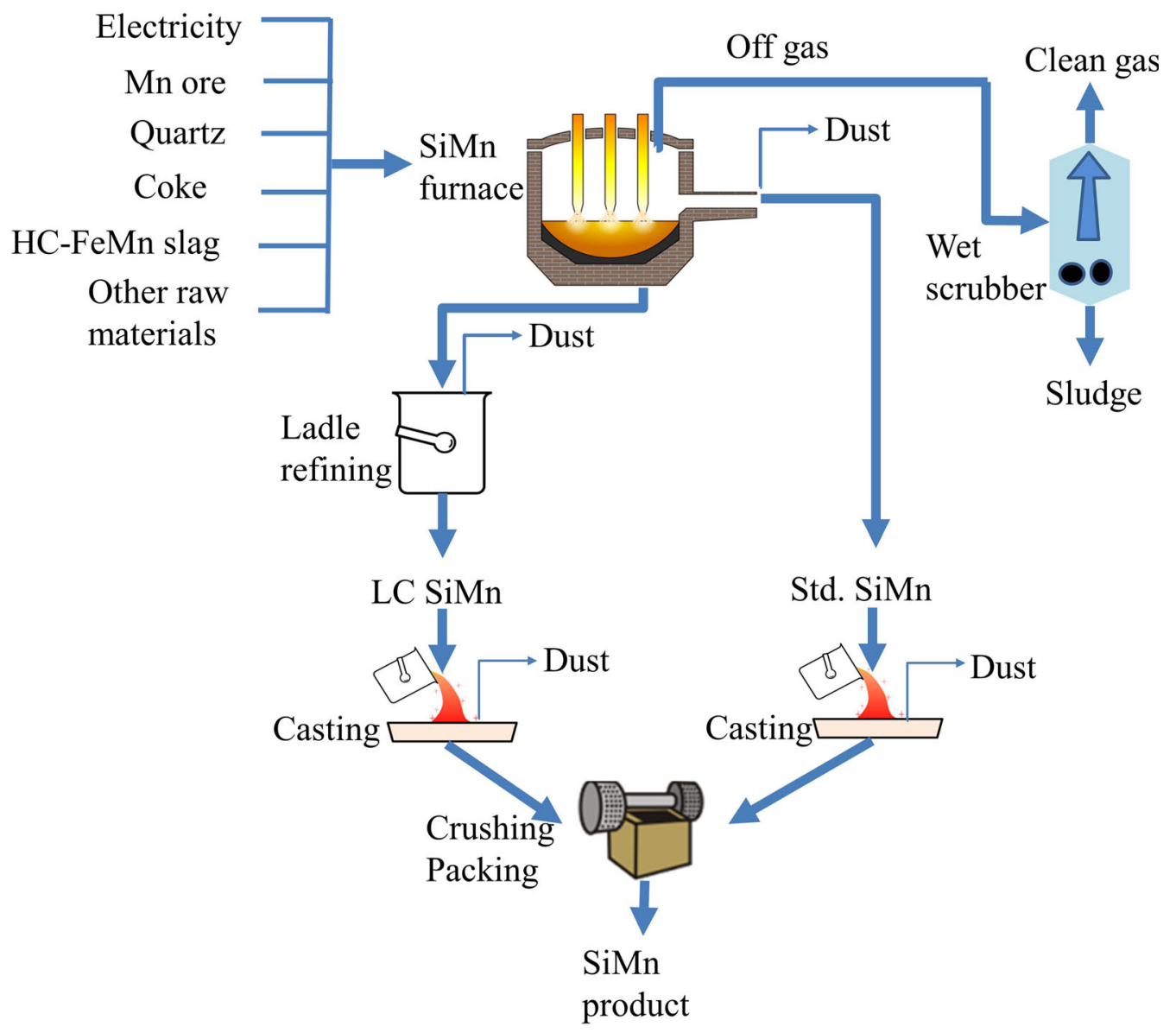

Fig. 1 - Overview of the material flows in a typical silicomanganese ferroalloy plant, after Olsen et al. ${ }^{[2]}$

"boiling-point-model" to predict the element distribution between the out-going phases in a $\mathrm{FeSi} / \mathrm{Si}$ furnace. According to this model, elements with boiling temperatures higher than the process temperature predominantly stay in the condensed phase, while elements with boiling temperatures lower than the process temperature mainly go off as fume or gas. If an element is stable as an oxide or sulfide, the boiling point of its compound is applicable. The fundamental principles of their work will also be applicable to elements present in the SiMn furnace, with the main difference that the SiMn process has slag as main output phase.

The distribution of both major and trace elements between dust, metal, and slag phases in the ladle refining process of metallurgical grade silicon (MG-Si) has been investigated by Næss et al. ${ }^{[4,5]}$ This study applied the "boiling-point-model" together with the Gibbs energies of oxidation of elements to explain the element distribution through the Si refining process. In an earlier publication, the current authors have also employed these two theories to explain the trace element behavior during the oxidation of a liquid SiMn alloy. ${ }^{[6]}$

Although the distribution of major elements ( $\mathrm{Si}, \mathrm{Mn}$, and $\mathrm{Fe}$ ) between the different product phases in the SiMn process is both well understood theoretically and thermodynamically, ${ }^{[1,7]}$ the behaviors of most minor and trace elements entering the process through the raw materials have not, with some exceptions, been reliably determined.
Shen et al.$^{[8]}$ performed a $\mathrm{Zn}$ mass balance from the input materials to the output (metal, slag, and dust) for both the FeMn and SiMn production processes. Zinc enters ferroalloy furnaces with $\mathrm{Mn}$ and Fe ores, alloy fines, and sinter. Most of the $\mathrm{Zn}$ in the raw materials reports to the Mn furnace dust. Meanwhile, the $\mathrm{Zn}$ content in both the FeMn and SiMn alloys is below 0.01 wt pct, and the industrial SiMn slag contains only approximately 0.002 wt pet $\mathrm{Zn}$. Fe, P, and As report to the metal as these elements are more easily reduced than $\mathrm{Mn} \cdot{ }^{[7]}$ It has also been determined that the major elements found in the particulate matter collected inside a SiMn alloy production plant are $\mathrm{Si}, \mathrm{Mn}$, and $\mathrm{O}$, with minor elements $\mathrm{Mg}, \mathrm{Ca}$, $\mathrm{Al}$, and $\mathrm{K}$. Detected trace elements are $\mathrm{Na}, \mathrm{Fe}, \mathrm{Zn}, \mathrm{Cu}$, and $\mathrm{Cl}^{\left[{ }^{[9]}\right.}$ However, the Mn sludge collected from both the FeMn and SiMn furnace processes seems to contain both the alkalis and $\mathrm{Zn}$ and in addition $\mathrm{Pb}, \mathrm{P}$, and $\mathrm{B}$, together with the water from the scrubber process. ${ }^{[10-12]}$

From a product point of view, it is of course imperative to understand the behavior of trace elements in the metal. For example, P may have harmful effects on the end product quality of the iron and steel industry. ${ }^{[13-15]}$ From an emission and waste handling point of view, the toxic element behavior is particularly important, especially since recycling of sludge and dust back to the furnace - a possible way to recover the $\mathrm{Mn}$ values in the dust - may lead to an up-concentration of certain elements over time. 


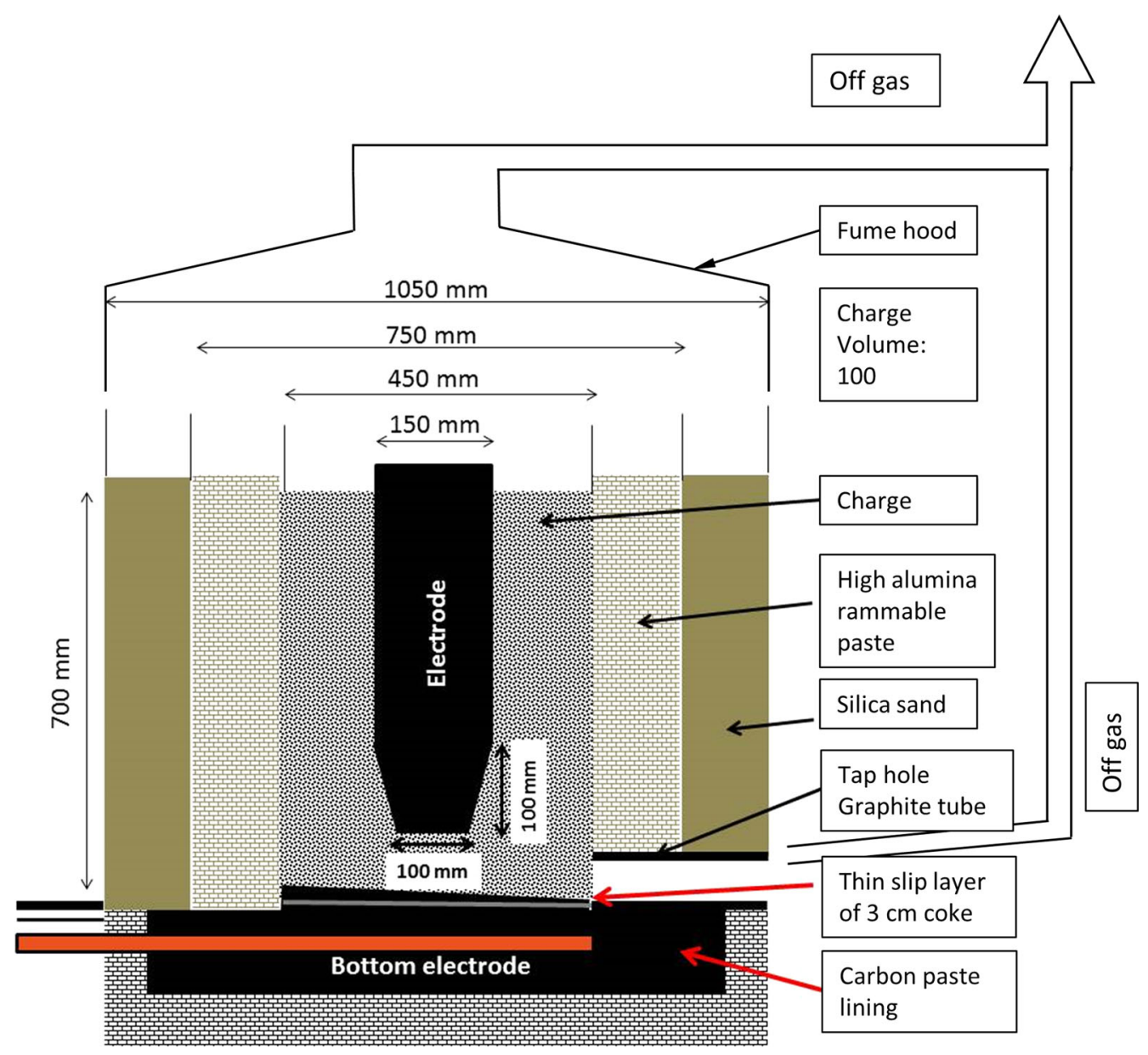

Fig. 2-Sketch of the pilot scale furnace.

The aim of the current work is to get a better understanding of the behavior of minor and trace elements and their distribution in the SiMn production process. In this article, element distribution results from a pilot-scale SiMn production campaign are reported. The results are compared with industrial products and by-product compositions, and with predictions based on thermodynamic modeling. This information will constitute a basis for further work aimed to quantify and control the behavior of key minor/trace elements in the SiMn alloy production process.

\section{EXPERIMENTAL}

\section{A. Pilot Scale Alloy Production}

A pilot scale experiment was performed in a $440 \mathrm{kVA}$ pilot furnace at the SINTEF/NTNU laboratories in Trondheim, Norway. The raw materials used in the production process were Asman 46 ore and $\mathrm{HC}$ FeMn slag, with addition of Snekkevik quartzite (from here on called "quartz"). Polish coke was used as the reducing agent. The raw materials were crushed and sieved to a particle size of 5 to $25 \mathrm{~mm}$. A schematic of the furnace is shown in Figure 2. The furnace was started with HC-FeMn charge ( $\mathrm{Mn}$ ore and coke) in order to reach high enough temperature for $\mathrm{SiO}_{2}$ reduction before quartz is added. This is critical to avoid a quartz layer in the coke bed that will disturb current and energy distribution in the furnace. The SiMn charge includes Mn ore, quartz, HC FeMn slag (from here on called FeMn slag), and coke.

The experiment was run for 11 hours. During the experiment, $1230 \mathrm{kWh}$ was supplied to the furnace. The furnace was tapped 12 times during the experiment, with the first tap 5 hours after starting the furnace. Subsequent taps were conducted approximately every 30 minutes. The furnace was shut down after the last tap. Of the 12 taps during the experiment, the first two were, according to XRF (Axios $4 \mathrm{KW}$ from PanAlytical) analysis, tapping FeMn alloy while the subsequent ten were SiMn alloy. The tapping time and type of alloys tapped are listed in Table I.

A fume hood was installed on top of the furnace and in front of the tap hole. A dust collector was set up at the end of the off-gas channel, and it was turned on from the time of starting the first SiMn charge until the furnace was stopped.

A process mass balance was carried out for the SiMn pilot production period, and the considered mass flows are illustrated in Figure 3(a). The SiMn production period starts with the first SiMn material charge and ends when the furnace was turned off. The amount of dust generated during the production process was 
calculated from the measurement data of dust concentration and off-gas flow rate. As a comparison, in a typical industrial $27 \mathrm{MW}$ submerged arc furnace, a charge consisting of $396 \mathrm{~kg} \mathrm{Mn}$ ore, $1593 \mathrm{~kg}$ HC-FeMn slag, $411 \mathrm{~kg}$ quartz, $360 \mathrm{~kg}$ coke, $100 \mathrm{~kg}$ dolomite, and $139 \mathrm{~kg} \mathrm{Si}$-sculls (from Si refining) is required to produce $1000 \mathrm{~kg}$ saleable SiMn product. At the same time, $1225 \mathrm{~kg} \mathrm{SiMn}$ slag is also produced. ${ }^{[1]}$ The mass flows through the typical industrial production process are also illustrated in Figure 3(b).

In comparison to the typical industrial production, no dolomite or Si-sculls and more $\mathrm{Mn}$ ore and quartz material per unit metal produced were used in the pilot scale experiment. While the pilot experiment is not identical to the industrial process, individual companies, and plants will use different proprietary charge mixes. As such, this pilot process constitutes an acceptable approximation of the industrial furnace process with the added benefit of allowing all data to be openly published.

Table I. Type of Alloys Tapped and Tapping Time

\begin{tabular}{lcc}
\hline Hours from Start $/ \mathrm{h}$ & $\begin{array}{c}\text { No. of } \\
\text { Tapping }\end{array}$ & $\begin{array}{c}\text { Type of Alloy } \\
\text { Tapped }\end{array}$ \\
\hline 5 & 1 & FeMn \\
5.5 & 2 & FeMn \\
6 & 3 & SiMn \\
6.5 & 4 & SiMn \\
7 & 5 & SiMn \\
7.5 & 6 & SiMn \\
8 & 7 & SiMn \\
8.5 & 8 & SiMn \\
9 & 9 & SiMn \\
9.5 & 10 & SiMn \\
10 & 11 & SiMn \\
10.5 & 12 & SiMn \\
\hline
\end{tabular}

*Alloy compositions given in Appendix I.

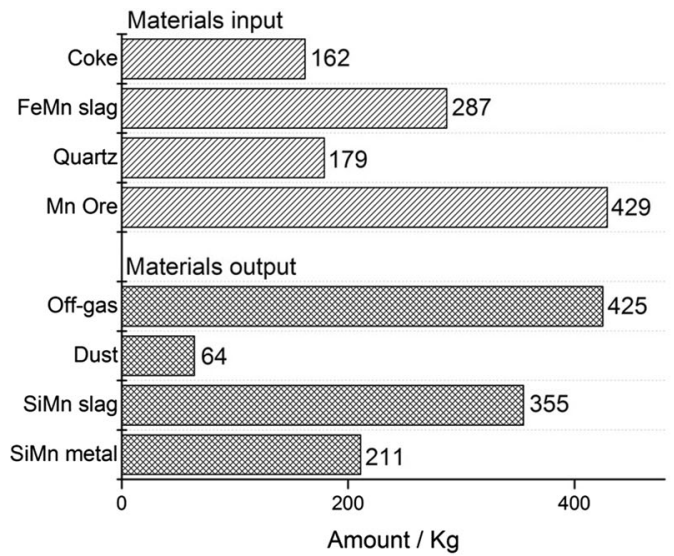

(a)

\section{B. Sampling and Analysis}

SiMn metal and slag samples were taken from every second tap, i.e., tap No. 4, 6, 8, 10, and 12. The off-gas system captured dust from the top of the furnace and dust from the tap hole during the tapping process simultaneously, and these two dust sources were hence mixed in the dust collector. A total of 15 samples were collected from the experiments, which included the 4 in-going raw materials, five metal samples (from different taps), five slag samples (from the same taps as metal samples) as well as one dust sample collected from the dust collector.

In order to be able to evaluate whether the collected dust sample was representative of industrial furnace dust, an industrial SiMn sludge sample was analyzed together with the pilot experiment dust. After drying the sample at $110{ }^{\circ} \mathrm{C}$ for 24 hours, the sample was ground to powder for characterization.

All samples were analyzed by Inductively Coupled Plasma Mass Spectrometry (ICP-MS) after dissolution in $0.5 \mathrm{~mL}$ concentrated $\mathrm{HF}, 0.5 \mathrm{~mL}$ concentrated $\mathrm{HNO}_{3}$, and $1.5 \mathrm{~mL}$ concentrated HCL, and digested in an ultra clave prior to ICP-MS analysis. A specific element detection limit in the sample (DL) was set by either the instrumental detection limit (IDL) or the black detection limit (BDL) for the given element, where the higher of the two was employed in the results assessment. If the detected element concentration was below its respective DL value, the result was omitted. Each sample was analyzed three times, and a relative standard deviation (RSD) value from ICP-MS analysis was also obtained. An analysis with an RSD value above 10 pct was considered unreliable. If an element concentration in a sample was below the detection value and/or with an RSD $>10$ pct, its concentration in that particular sample was reported as $0 \mathrm{ppm}$. Most omitted elements had concentrations well below $1 \mathrm{ppm}$ in the analyzed samples.

Slag samples were also analyzed by Zeiss Supra 55 field emission scanning electron microscopy (SEM) with energy dispersive X-ray spectrometry (EDS) in order to detect and characterize any metal content in the slag.

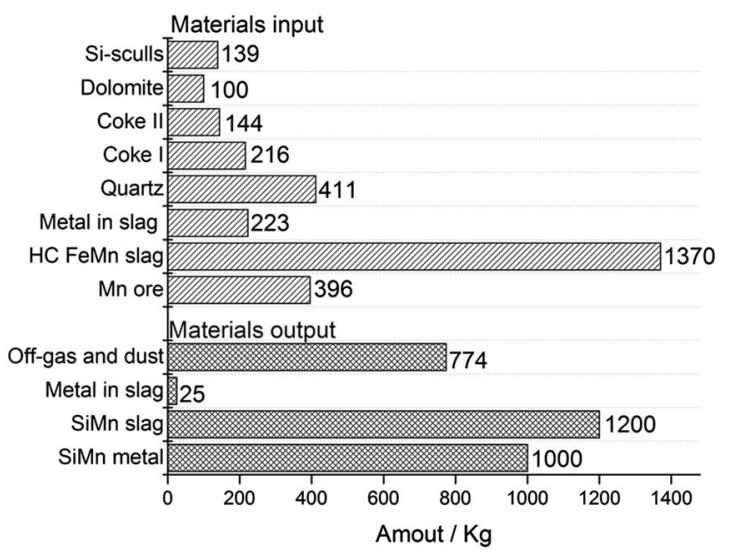

(b)

Fig. 3-(a) Mass balance for the entire silicomanganese production period of the pilot scale experiment and (b) a typical industrial 27MW submerged arc furnace production process. 


\section{EXPERIMENTAL RESULTS AND DISCUSSIONS}

\section{A. Element Mass Balance}

While 64 elements were included in the ICP-MS analysis of the raw materials (coke, quartz, Mn ore, and FeMn slag), only 56 element analysis results were considered reliable. For the metal, slag, and dust samples, 55 element results were considered reliable. Analysis results of 51 common elements were considered reliable for all samples. The average compositions of SiMn metal and slag were calculated from the analysis results for the five metal and slag samples, respectively. Based on the material mass balance, an elemental mass distribution between in-going and out-going phases are presented in Figures 4 and 5, respectively. Mercury is only detected in the $\mathrm{Mn}$ ore raw material, and then reports to the off-gas. This is in agreement with current emission reporting data. ${ }^{[16]}$ Hence, $\mathrm{Hg}$ is not included in the reported 51 elements. The 51 elements are classified into four groups, according to their chemical properties, as given in Table II.

As shown in Figure 4, the FeMn slag has the highest contribution of almost all the in-going minor/trace elements, while the Mn ore makes the second highest contribution. In total, quartz and coke contain less of the impurities than the other two raw materials. Figure 5 shows the mass flows out of the furnace, where elements get redistributed into metal, slag, and dust after the smelting process.
From the SEM study, it was confirmed that the small amount of $\mathrm{Fe}$ and $\mathrm{P}$ appearing in the ICP-MS analysis of the SiMn slag phase is mainly caused by micron-sized small metal prills trapped in the slag, a commonly observed phenomenon in the industry, see Figure 6. The real content of these elements in the slag is thus negligible.

\section{B. Detailed Description of Element Behavior in the SiMn System}

The boiling and melting temperatures of all the 51 elements included in the analysis are plotted in Figure 7, and the Gibbs energies of oxidation for all the elements are illustrated in Figure 8 . The data were obtained from FactSage 7.1 through the FactPS and FToxid databases. ${ }^{[17]}$

Most of the dust was generated at the top of the furnace, under reducing conditions (in the presence of solid carbon). The dust collected from the tap hole was formed due to the reaction between high-temperature molten metal and oxygen in ambient air (oxidizing conditions). ${ }^{[18]}$ Under both conditions, assuming ideal behavior, elements with higher Gibbs energies of oxidation than $\mathrm{Mn}$ are reduced and would then predominantly report to metal or dust (depending on boiling temperatures of elements). Meanwhile, elements with lower Gibbs energies of oxidation than $\mathrm{Mn}$ would mainly go to slag or dust (depending on boiling temperatures of compounds). Elements forming volatile

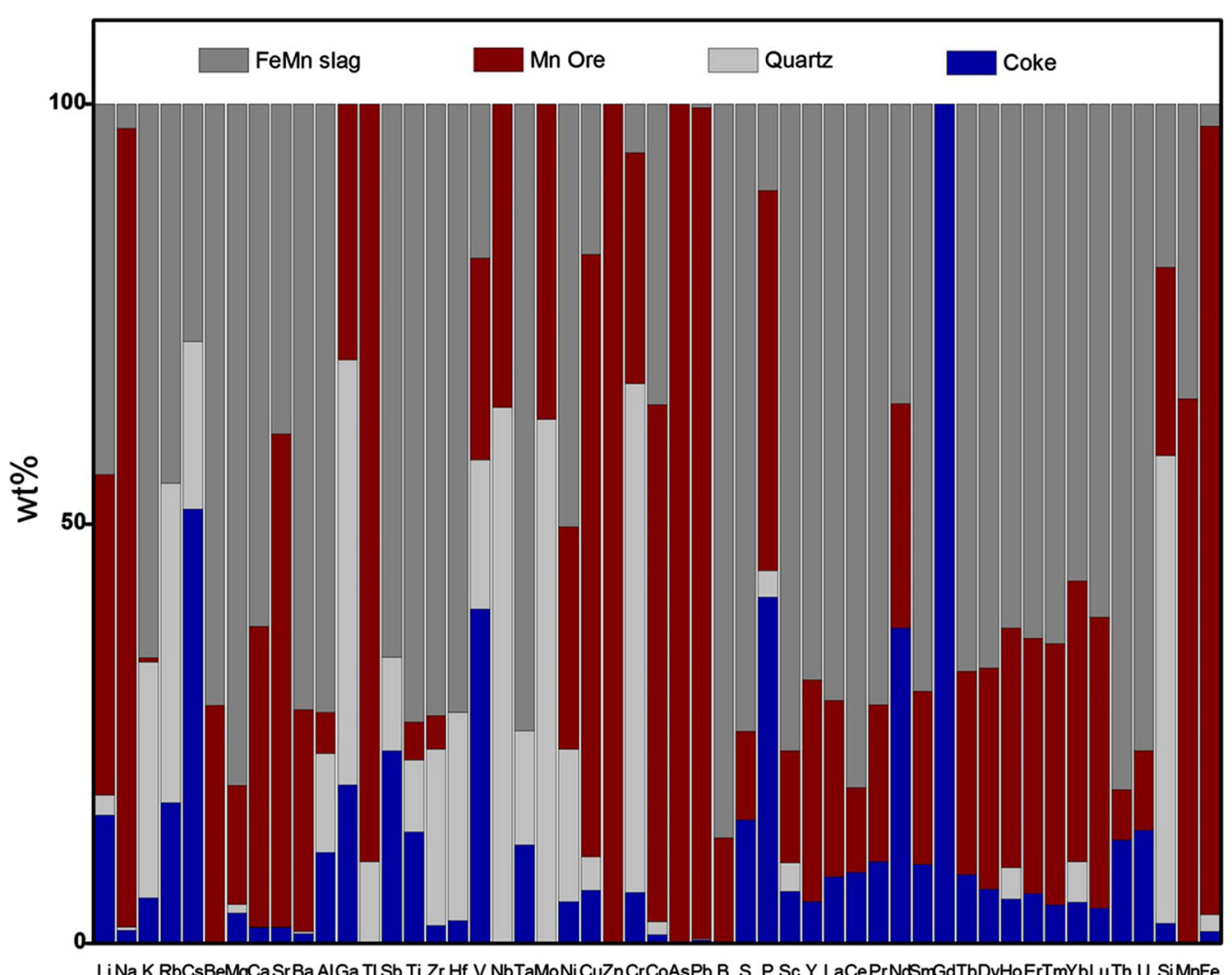

Fig. 4-Distribution of elements in the mass flows into the furnace: raw materials. 


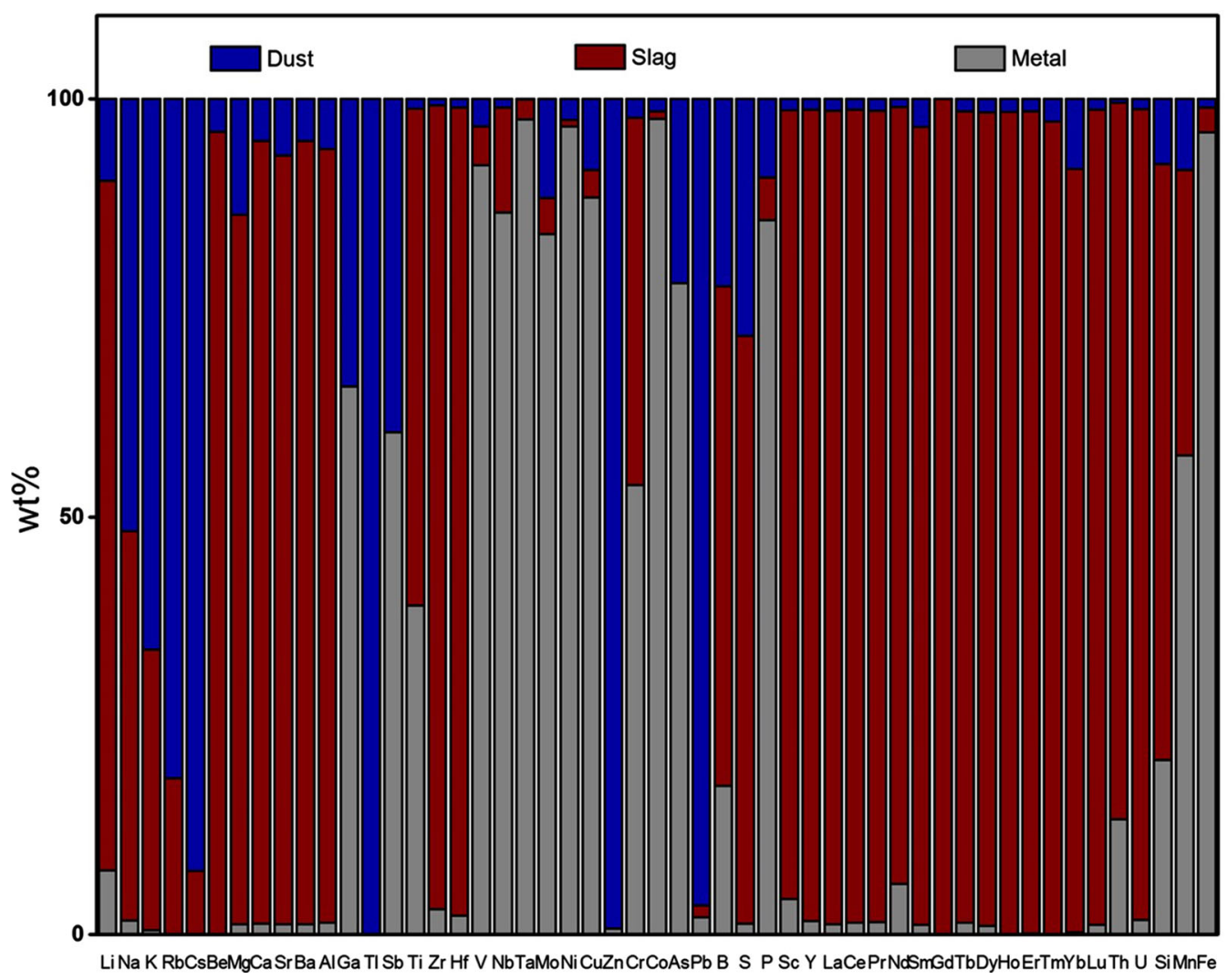

Fig. 5-Distribution of elements in the mass flows out of the furnace: metal, slag, and dust.

Table II. Elements Detected by ICP-MS

\begin{tabular}{ll}
\hline Groups & \multicolumn{1}{c}{ Elements } \\
\hline Alkali metal & $\mathrm{Li}, \mathrm{Na}, \mathrm{K}, \mathrm{Rb}, \mathrm{Cs}, \mathrm{Be}, \mathrm{Mg}, \mathrm{Ca}, \mathrm{Sr}, \mathrm{Ba}$ \\
Base and transition metal & $\mathrm{Al}, \mathrm{Ga}, \mathrm{Tl}, \mathrm{Sb}, \mathrm{Ti}, \mathrm{Zr}, \mathrm{Hf}, \mathrm{V}, \mathrm{Nb}, \mathrm{Ta}, \mathrm{Mo}, \mathrm{Ni}, \mathrm{Cu}, \mathrm{Zn}$ \\
Non-metal & $\mathrm{B}, \mathrm{S}, \mathrm{P}$ \\
Toxic metal & $\mathrm{Cr}, \mathrm{Co}, \mathrm{As}, \mathrm{Pb}$ \\
Lanthanide and actinide metal & $\mathrm{Sc}, \mathrm{Y}, \mathrm{La}, \mathrm{Ce}, \mathrm{Pr}, \mathrm{Nd}, \mathrm{Sm}, \mathrm{Gd}, \mathrm{Tb}, \mathrm{Dy}, \mathrm{Ho}, \mathrm{Er}, \mathrm{Tm}, \mathrm{Yb}, \mathrm{Lu}, \mathrm{Th}, \mathrm{U}$ \\
Main elements & $\mathrm{Fe}, \mathrm{Si}, \mathrm{Mn}$ \\
\hline
\end{tabular}

oxides may also report to the dust. However, interactions between different species in the solution phases (metal and slag) should also be taken into account to explain the element distribution between phases, as described below. The non-ideal behavior of metal and slag species was adapted from the FactSage FTlite and FToxid databases, respectively. ${ }^{[17]}$

As shown in the overview Figures 4 and 5, most of the alkali metals, with the exception of $\mathrm{K}$, enter the process through the $\mathrm{Mn}$ ore and FeMn slag and are redistributed to the slag and dust in the reduction process as shown in more detail in Figure 9. The alkalis are present only in very small concentrations in the metal $-\mathrm{Ca}$ and $\mathrm{Mg}$ being detected to be below $2500 \mathrm{ppm}$. The alkali elements all have low boiling points compared to the process temperature. $\mathrm{K}, \mathrm{Na}, \mathrm{Rb}$, and $\mathrm{Cs}$ also have higher Gibbs energies of oxidation than $\mathrm{Mn}$, and therefore report to the dust through vaporization and subsequent oxidation.
Lithium and alkaline earth metals $\mathrm{Mg}, \mathrm{Ca}, \mathrm{Sr}$, and $\mathrm{Ba}$ form very stable oxides. As these elements enter the process as oxides, they naturally report to slag. However, as $\mathrm{Li}, \mathrm{Mg}, \mathrm{Ca}, \mathrm{Sr}$, and $\mathrm{Ba}$ all have relatively low boiling points, they also end up in the dust to a certain extent. Beryllium mainly reports to the slag, due to its high boiling point and very low Gibbs energy of oxidation.

The base and transition metals originate mainly from the FeMn slag and redistribute to the SiMn metal, slag, and dust, as seen in Figure 10. Coke, quartz, and FeMn slag all contain a certain amount of $\mathrm{Al}$, which mostly reports to the slag and to a lesser extent dust (through formation of the $\mathrm{AlO}_{\mathrm{x}}$ gas $^{[19]}$ ) in the SiMn process. Zinc oxide stems from the $\mathrm{Mn}$ ore and is easily reduced to volatile elemental zinc in the furnace, leaving with the off-gas and entering the dust as oxide, which is in agreement with the results of Shen and co-workers. ${ }^{[8]}$ 

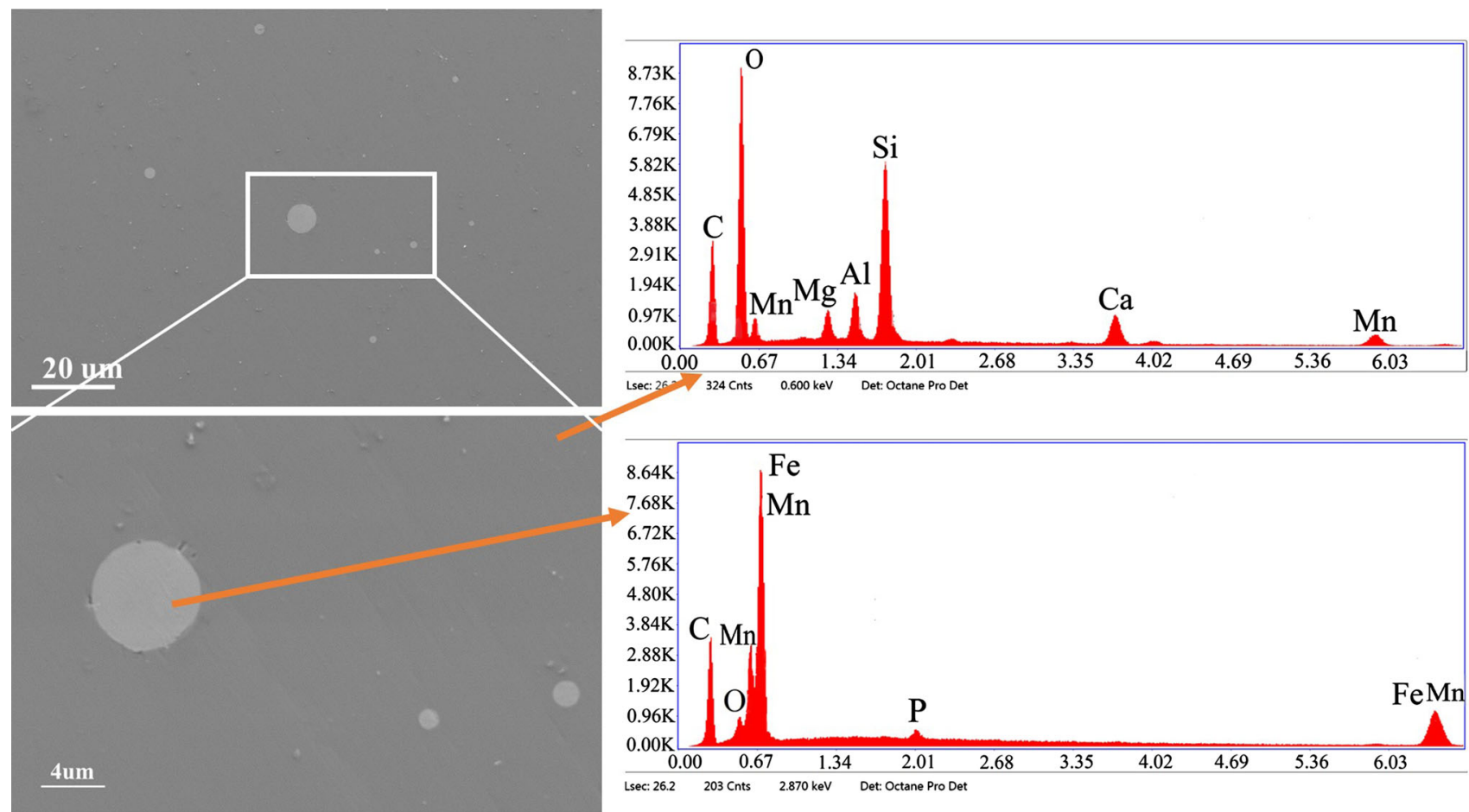

Fig. 6-Metal prills in slag containing $\mathrm{Fe}, \mathrm{Mn}, \mathrm{Si}$, and $\mathrm{P}$, as observed by SEM and EDS.

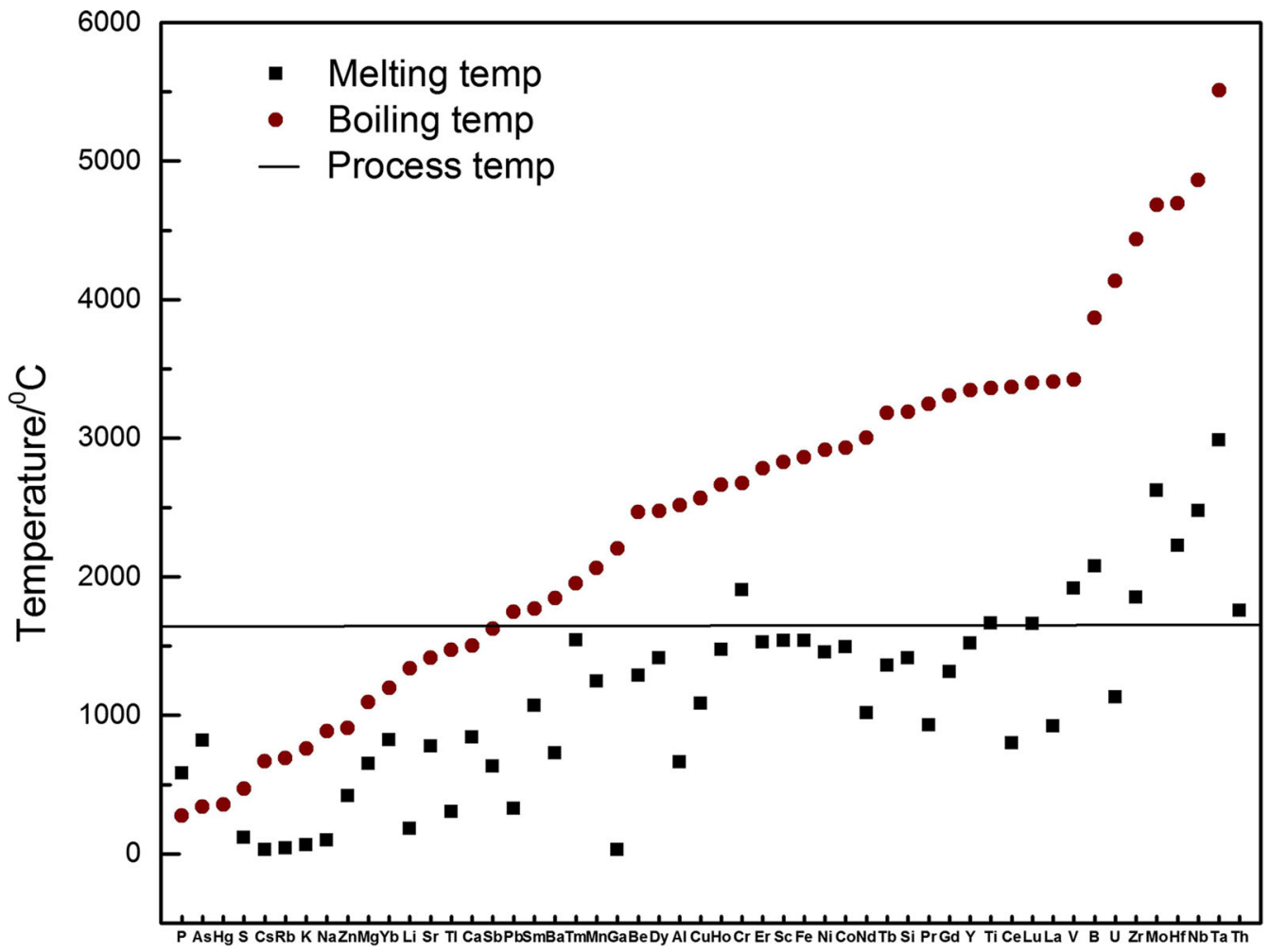

Fig. 7-The melting and boiling temperatures of the elements plotted with the process temperature of the furnace $\left(-1600^{\circ} \mathrm{C}\right)$. 


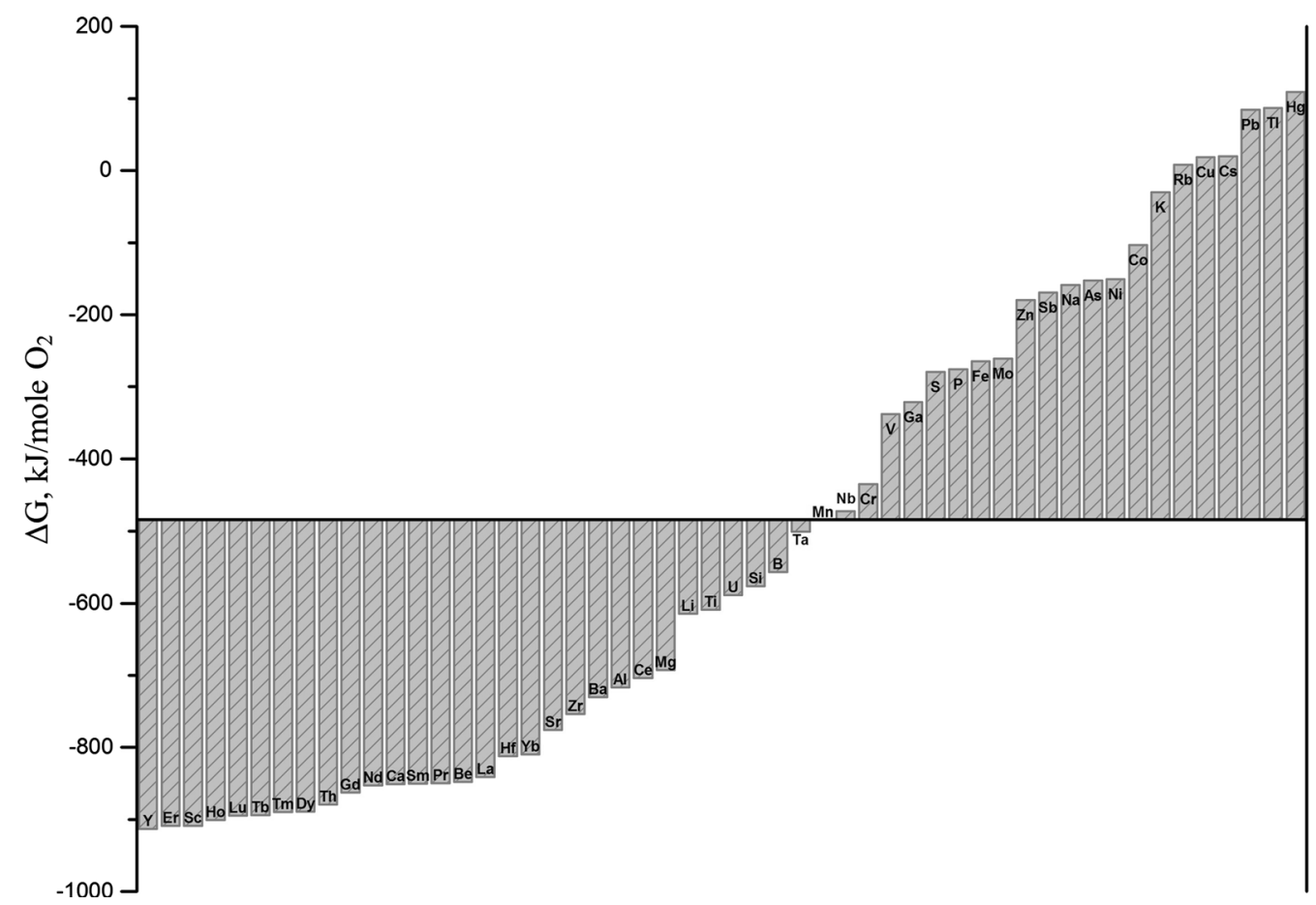

Fig. 8 - Gibbs energies of oxidation of the elements. The Gibbs energies are calculated for one mole of oxygen and the most stable state of the oxides.

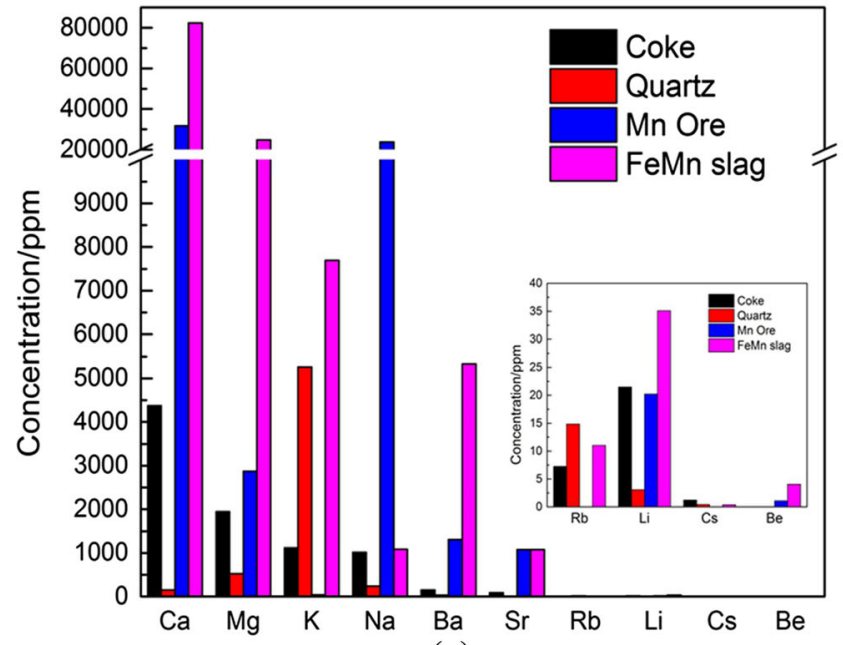

(a)

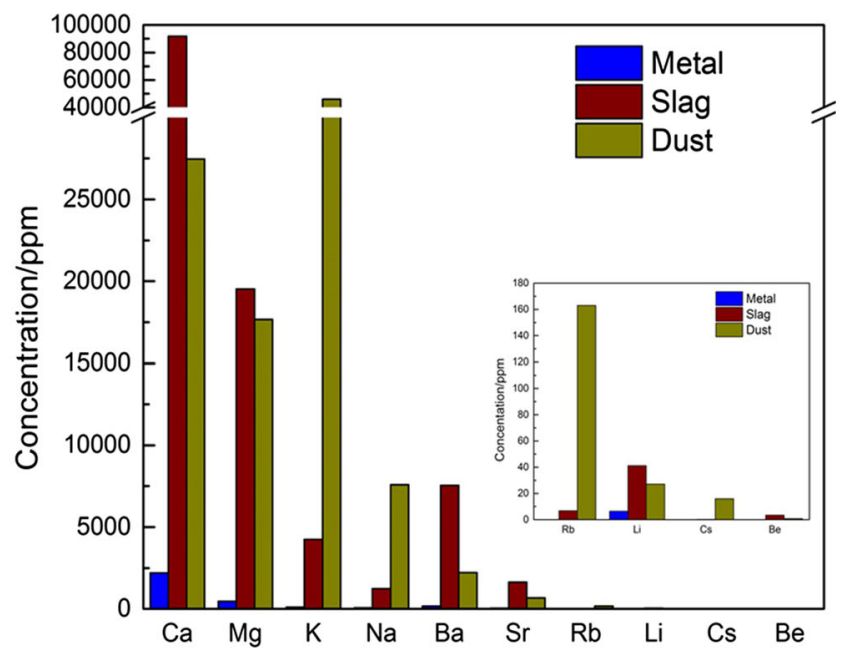

(b)

Fig. 9-Concentrations of alkali metals in, (a) raw materials and, (b) metal, slag, and dust. Please note the differences in order of magnitude enabled by the sectioned $y$-axis.

The elements $\mathrm{Al}, \mathrm{Zr}$, and $\mathrm{Hf}$ behave as expected, i.e., are mainly found in the slag phase, as they form oxides more stable than the Mn oxides. Titanium reports to both metal and slag in a similar concentration, and the elements $\mathrm{Cu}, \mathrm{V}, \mathrm{Nb}, \mathrm{Ta}, \mathrm{Mo}$, and $\mathrm{Ni}$ mainly report to the metal. This would be expected for $\mathrm{Cu}, \mathrm{V}, \mathrm{Nb}, \mathrm{Mo}$, and $\mathrm{Ni}$ which have high boiling points and are more noble than Mn. Tantalum, on the other hand, has a relatively similar Gibbs energy of oxidation to that of $\mathrm{Mn}$, and $\mathrm{Ti}$ has a much lower Gibbs energy of oxidation than Mn. Titanium displays negative deviation from ideality in both $\mathrm{Si}$ and $\mathrm{Mn}$, as adapted from FactSage databases.
The presence of Ta in the metal phase can be related to its possible negative deviation behavior. Zinc, Ga, Tl, and $\mathrm{Sb}$ are mainly present in the dust, as they have higher Gibbs energies of oxidation than $\mathrm{Mn}$ and relatively low boiling temperatures.

The concentrations of toxic metals in the input and output phases are shown in Figure 11. Lead mainly originates from $\mathrm{Mn}$ ore and redistributes to the dust because of its low boiling temperature. Chromium mostly originates from quartz and redistributes to metal, slag, and dust - the dust having the lowest concentration of $\mathrm{Cr}$ and metal the highest. Cobalt 


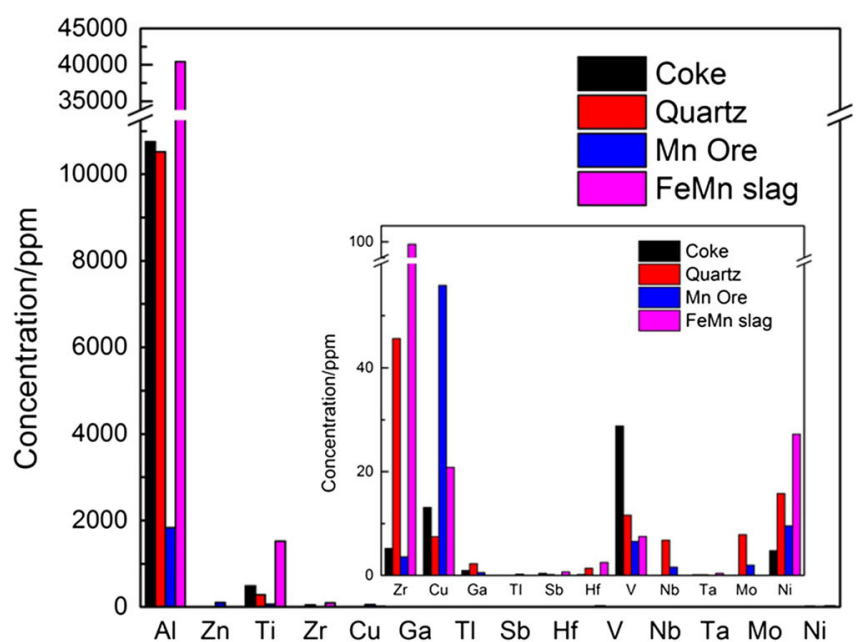

(a)

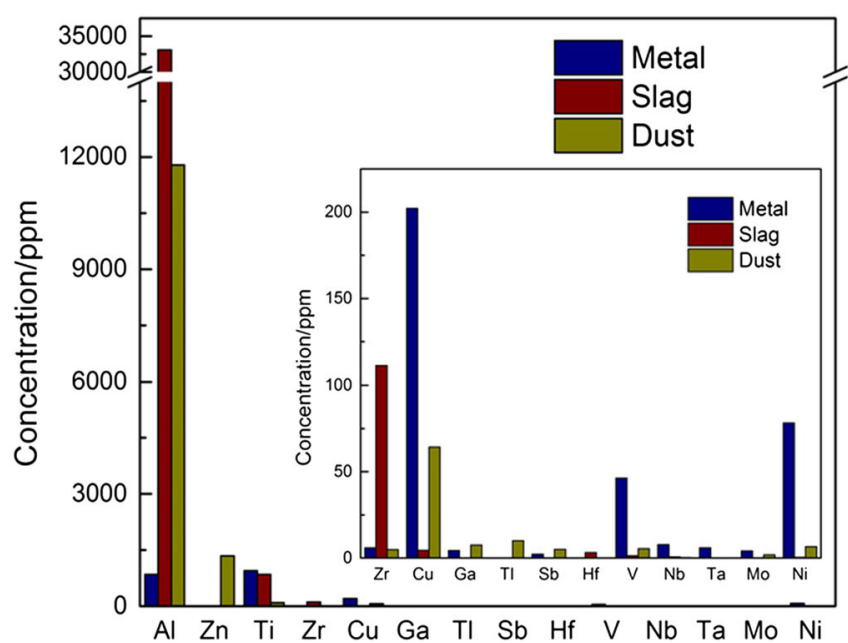

(b)

Fig. 10 - Concentrations of base and transition metals in, (a) raw materials and, $(b)$ metal, slag, and dust.

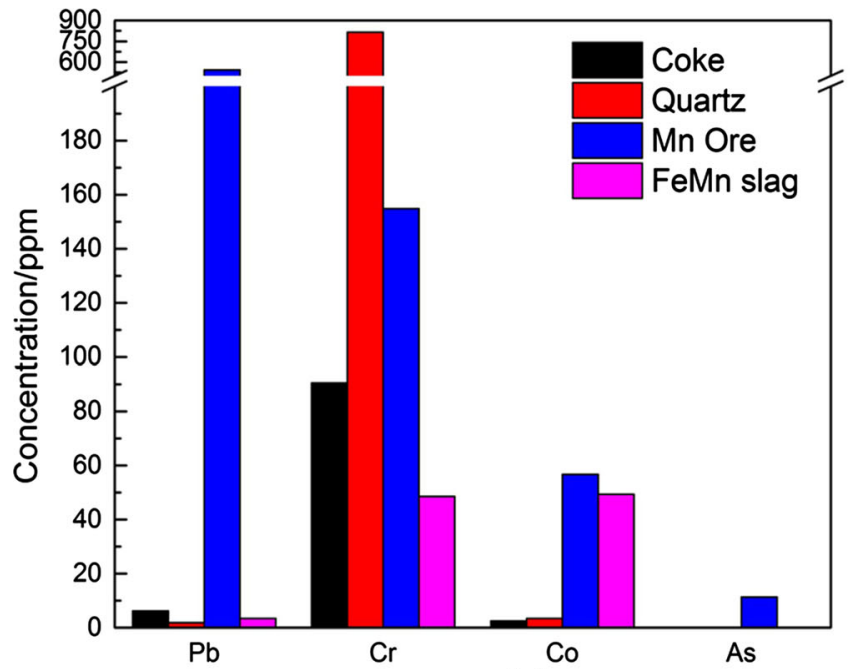

(a)

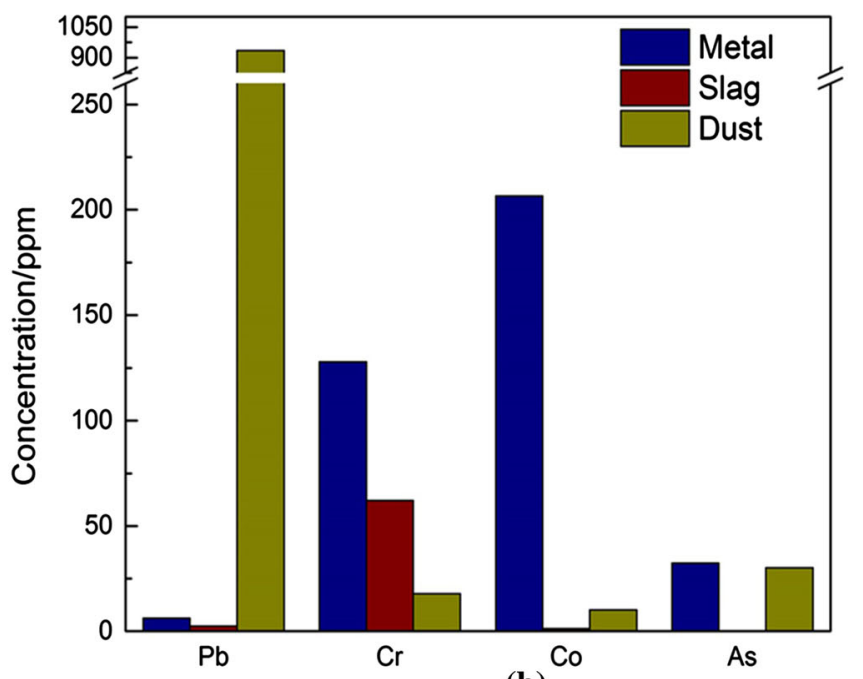

(b)

Fig. 11-Concentrations of toxic metals in, (a) raw materials and, (b) metal, slag, and dust.

originates from $\mathrm{Mn}$ ore and FeMn slag and predominantly enters the alloy product. Chromium and Cobalt both have high boiling temperatures and higher Gibbs energies of oxidation than $\mathrm{Mn}$, explaining their metal-preference. Arsenic originates from $\mathrm{Mn}$ ore and exits the furnace with the metal and dust phases in almost equivalent concentrations, which is caused by competing properties, i.e., high vapor pressure, higher Gibbs energy of oxidation than $\mathrm{Mn}$, and negative deviation from ideality in both $\mathrm{Si}$ and $\mathrm{Mn} .{ }^{[6]}$ Considering the amount (mass) of metal and dust generated during this process, the majority of As exits the furnace with the metal phase, as seen in Figure 5.

Concentrations of non-metal elements in raw materials and products are illustrated in Figure 12. Boron and Sulfur mainly originate from the FeMn slag, with some contribution of S from the coke. Both elements mainly exit the furnace with the slag and dust, with dust having the highest concentration of these elements. Sulfur is more easily reduced than $\mathrm{Mn}$, and has low boiling point and relatively high vapor pressure; thus, it largely reports to the dust. There is also a certain amount of $\mathrm{S}$ reporting to the slag, mainly in the form of $\mathrm{MnS}$. Boron on the other hand is stable as $\mathrm{B}_{2} \mathrm{O}_{3}$ at the process temperature, but the boiling point of $\mathrm{B}_{2} \mathrm{O}_{3}$ is $450{ }^{\circ} \mathrm{C}$ (much lower than the process temperature), and hence, $B$ reports to both slag and dust.

Phosphorous enters the SiMn process through the coke and $\mathrm{Mn}$ ore. The $\mathrm{P}$ phase distribution in the furnace is affected by competing chemical reactions; $\mathrm{P}$ having a high elemental vapor pressure but higher Gibbs energy of oxidation than $\mathrm{Mn}$ and negative deviation from ideality in both $\mathrm{Si}$ and Mn mainly enters the metal phase and only partly enters the dust.

Concentrations of lanthanide and actinide metals are shown in Figure 13. Most of the elements except Nd mainly originate from the FeMn slag, and report to the slag after the melting process. This behavior is expected 


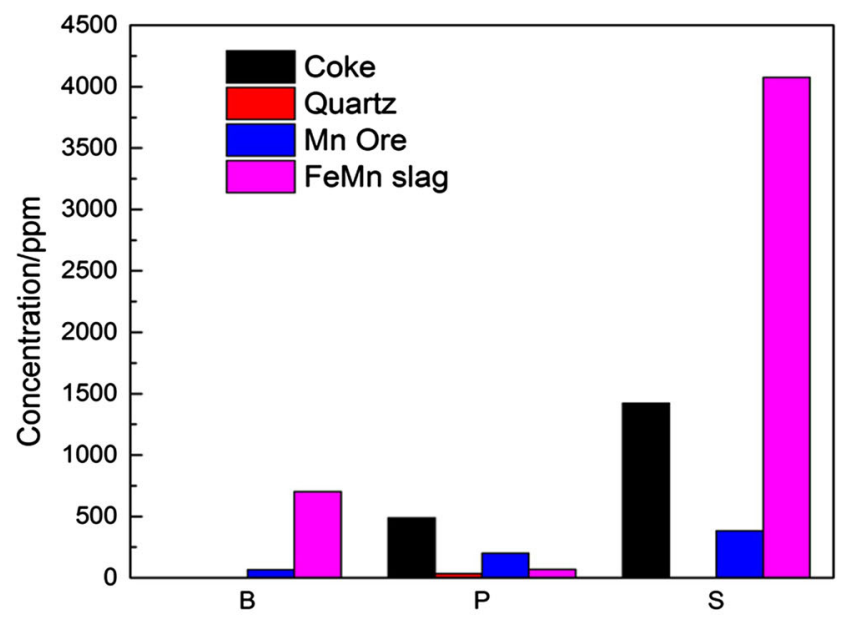

(a)

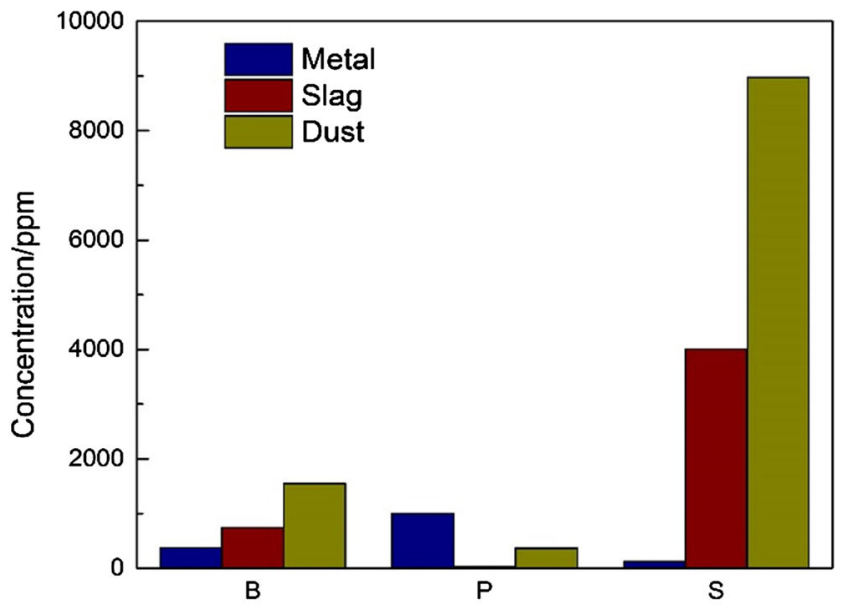

(b)

Fig. 12 - Concentrations of non-metals in, (a) raw materials and, (b) metal, slag, and dust.

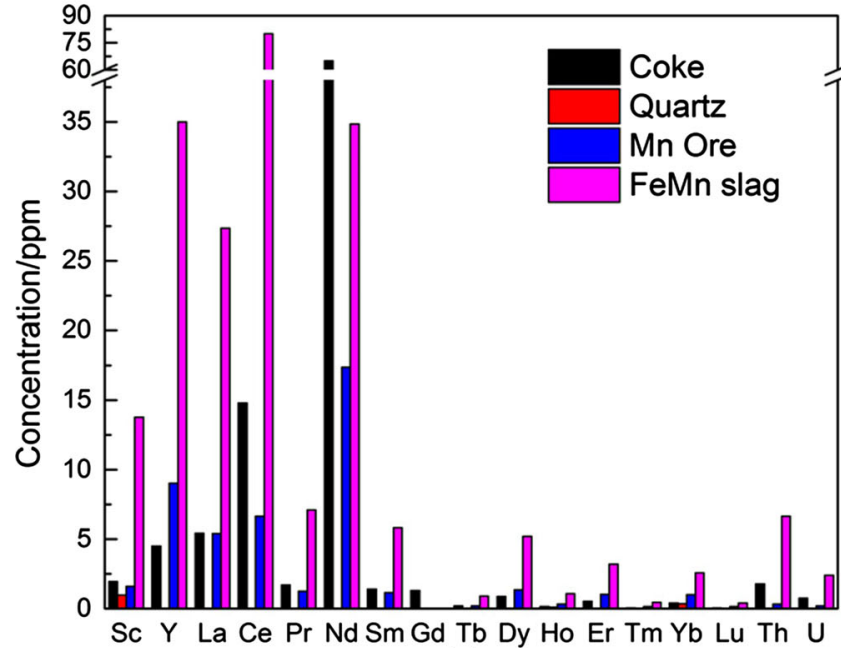

(a)

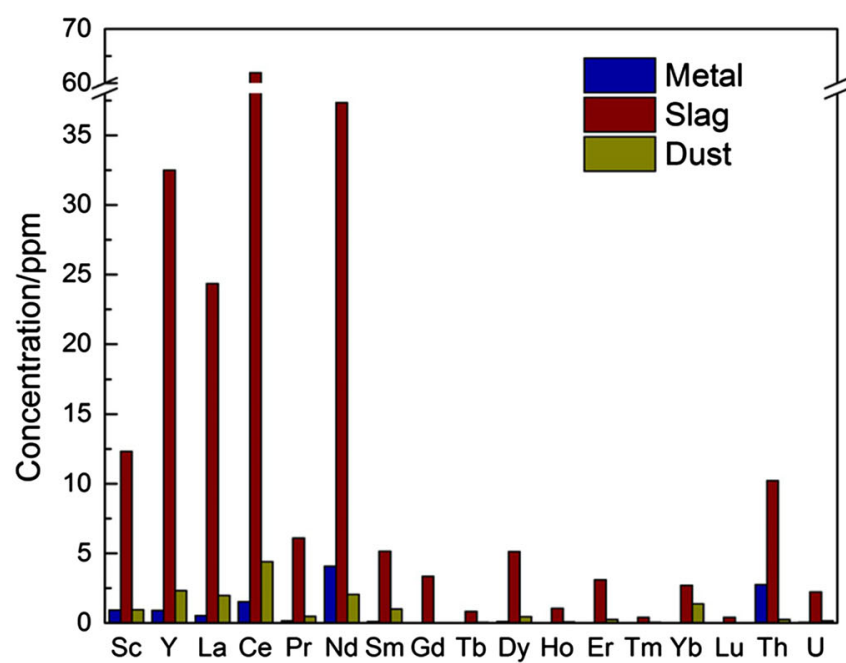

(b)

Fig. 13 - Concentrations of lanthanide and actinide metals in, (a) raw materials and, (b) metal, slag, and dust.

given their low Gibbs energies of oxidation. Neodymium originates from the coke, FeMn slag, and Mn ore, then also reports to the slag.

\section{Comparison Between Pilot Experiment Dust and Industrial SiMn Sludge}

A comparison of the element concentrations between industrial SiMn sludge (the "wet dust" from scrubbing of the industrial furnace off-gas at Eramet Kvinesdal) and dust from the pilot furnace campaign was also carried out.

As shown in Figure 14, most of the elements have similar concentrations in both SiMn sludge from industrial operations and dust from the pilot experiment, indicating that the pilot furnace campaign dust is representative for a typical industrial furnace dust, using similar raw materials as inputs.

\section{THERMOCHEMICAL SIMULATION}

In order to compare the experimental results to predicted behavior of elements, equilibrium calculations for the distribution of 21 elements were carried out using the 'Equilib' module of the FactSage7.1 thermochemical software. ${ }^{[17]}$ The compositions of the raw materials coke, FeMn slag, Mn ore, and quartz were considered to calculate the produced SiMn liquid metal, slag, and fume (off-gas and dust) compositions. Thermodynamic descriptions of the SiMn melt (Si-Mn-Fe-Li-Na-K-MgCa-Ba-B-Al-Pb-P-S-Ti-Zr-Cr-Co-Ni-Cu-Zn) were taken from the FTlite database. Thermodynamic properties of the oxide system $\mathrm{SiO}_{2}-\mathrm{TiO}_{2}-\mathrm{ZrO}_{2}-\mathrm{Al}_{2} \mathrm{O}_{3}-\mathrm{B}_{2} \mathrm{O}_{3}$ $\mathrm{Ti}_{2} \mathrm{O}_{3}-\mathrm{MnO}-\mathrm{FeO}-\mathrm{CoO}-\mathrm{NiO}-\mathrm{Cu}_{2} \mathrm{O}-\mathrm{ZnO}-\mathrm{CrO}-\mathrm{Cr}_{2} \mathrm{O}_{3}-\mathrm{P}$ bO-CaO-MgO-BaO- $\mathrm{Li}_{2} \mathrm{O}-\mathrm{Na}_{2} \mathrm{O}-\mathrm{K}_{2} \mathrm{O}-\mathrm{S}-\mathrm{P}$ were adapted from the FToxid database. Thermodynamic properties of gas species and pure components were taken from the 


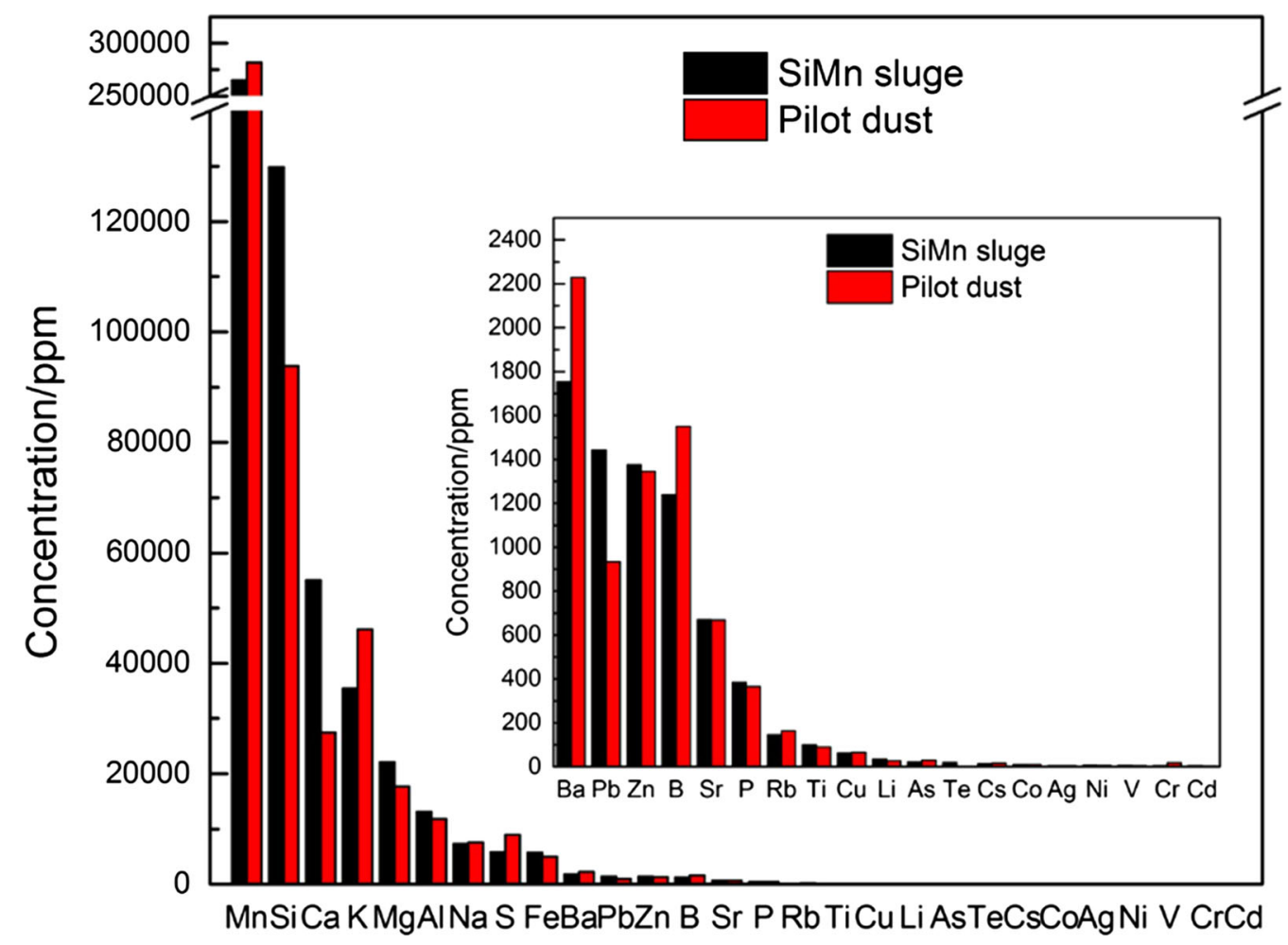

Fig. 14 Composition comparison of industrial SiMn sludge and dust from pilot furnace campaign.

FactPS database. In the selected system, 243 solutions, 1330 pure solids, and 248 gas species including 6117 total species could form as products. However, only the gas, liquid slag, and liquid metal phases were stable at the temperature $1600^{\circ} \mathrm{C}$ and composition studied.

The model calculations were carried out under the following process assumptions:

- No concentration gradients exist in the product metal and slag phases.

- The fume (off-gas and dust) was assumed to be generated from the furnace reduction smelting alone. The fume generation from the tapping process was assumed to be negligible in comparison to the furnace fume.

- Reactions between the metal, slag, and fume reached equilibrium.

- The process temperature $1600{ }^{\circ} \mathrm{C}$ was used in the simulations.

According to the model, $224 \mathrm{~kg} \mathrm{SiMn}$ metal, $356 \mathrm{~kg}$ SiMn slag, and $475 \mathrm{~kg}$ fume were generated from reactions of in-going raw materials in the furnace. A comparison between experimental data and modeled data is listed in Table III. The modeled fume includes both off-gas and dust. Since the modeled off-gas amount was estimated to be about $411 \mathrm{~kg}$ using Scheil-Gulliver cooling of the 'Equilib' module in FactSage, the remaining $64 \mathrm{~kg}$ is dust. It is believed that Scheil-Gulliver cooling gives a good estimation of solute redistribution during cooling of the gas phase. The concentrations of the modeled elements for the produced SiMn metal, slag, and dust are illustrated in Figures 15 through 17, respectively, where these values are compared with the experimental results.

The calculated concentrations of 8 elements $\mathrm{Si}, \mathrm{Mn}$, $\mathrm{Fe}, \mathrm{P}, \mathrm{Cu}, \mathrm{Ni}, \mathrm{Co}$, and $\mathrm{Li}$ show good correlation with those measured in the metal phase. Lead and chromium measured and modeled values in metal are within the same order of magnitude, as depicted in Figure 15. In the dust, there are large discrepancies for $\mathrm{Ba}, \mathrm{Zr}, \mathrm{Ni}, \mathrm{Co}$, $\mathrm{Ti}, \mathrm{Ca}$, and $\mathrm{Al}$, as shown in Figure 17. The modeled concentrations of the other 14 elements are in the same orders of magnitude as the corresponding experimental concentrations in dust. In the slag phase, there are large differences for the elements $\mathrm{Pb}, \mathrm{Cu}, \mathrm{Ni}, \mathrm{Co}, \mathrm{Fe}, \mathrm{P}$, and $\mathrm{Li}$ (the concentration of $\mathrm{Li}$ in the modeled slag phase is 0 wt pct), and the largest difference is found for $\mathrm{P}$, for which the theoretical concentration in slag is much lower than the experimental result obtained by ICP-MS, as illustrated in Figure 16. However, P is only detected in micron-sized metal prills which are entrapped into the slag by SEM-EDS. The only P component of the slag in the current FactSage FToxid database is phosphate $\left(\mathrm{P}_{2} \mathrm{O}_{5}\right)$. However, under reducing atmosphere, $\mathrm{P}$ exists largely as phosphide ${ }^{[20,21]}$ and due to the lack of phosphide components in the current FToxid slag database, the distribution between phases could not be reliably modeled. This resulted in a large discrepancy between experimental and calculated $\mathrm{P}$ concentrations in the slag. 
Table III. Comparison of Experimental Data and Modeled Data

\begin{tabular}{|c|c|c|c|c|c|}
\hline & \multirow[b]{2}{*}{ SiMn Metal/kg } & \multirow[b]{2}{*}{ SiMn Slag/kg } & \multicolumn{3}{|c|}{ Fume/kg } \\
\hline & & & Off-Gas & Dust & Total \\
\hline Experimental data & 211 & 355 & 425 & 64 & 490 \\
\hline Modeled data & 224 & 356 & 411 & 64 & 475 \\
\hline
\end{tabular}

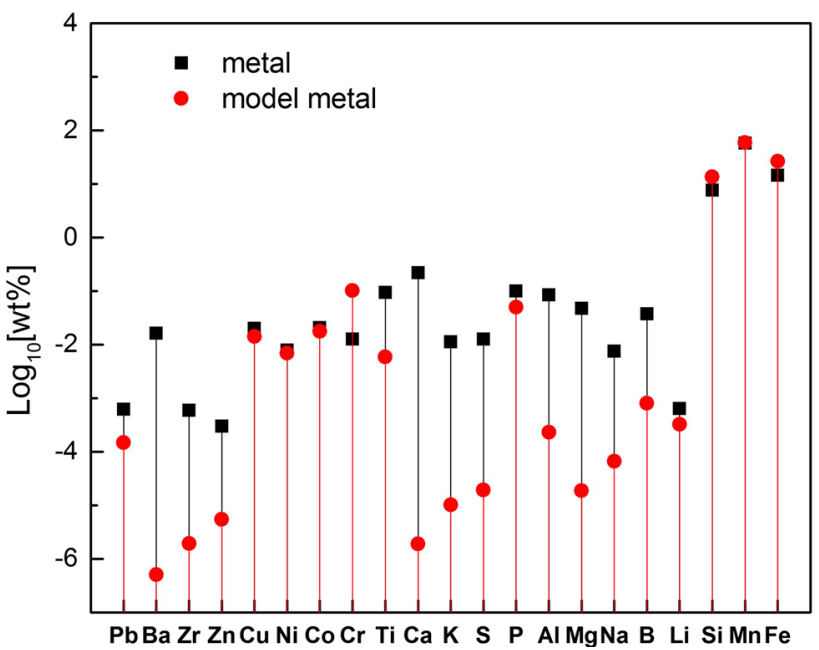

Fig. 15-Comparison of modeled and experimental concentrations of 21 elements in the SiMn metal. Note the logarithmic $y$-axis.

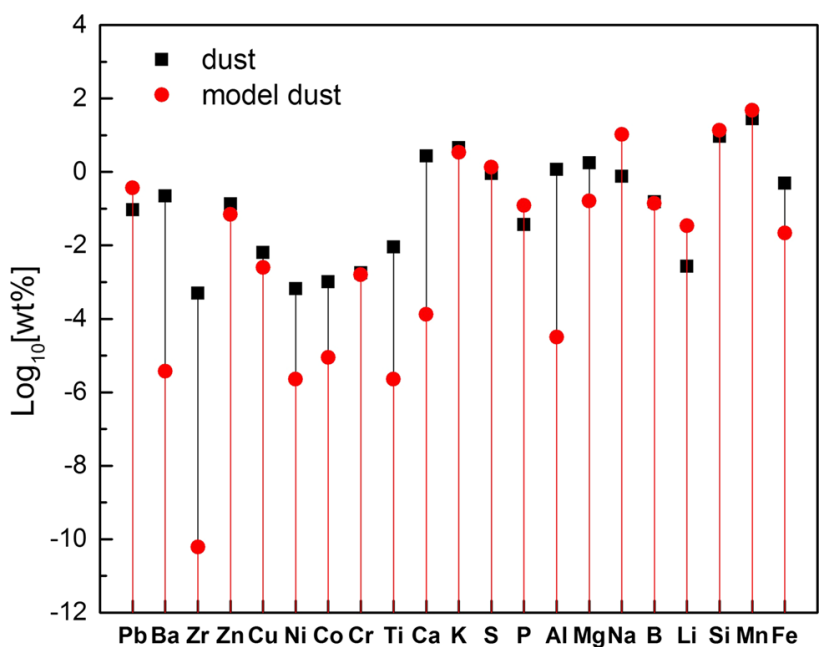

Fig. 17-Comparison of modeled and experimental concentrations of 21 elements in the SiMn dust. Note the logarithmic $y$-axis.

The discrepancy between the modeled and experimental data may be explained by lack of accurate thermodynamic descriptions for several minor species in the metal, slag, and gas phases, e.g., as explained for $\mathrm{P}$ in the slag. However, the present model also excludes the kinetic effects while, in reality, the system may be far from equilibrium. For the major components (such as

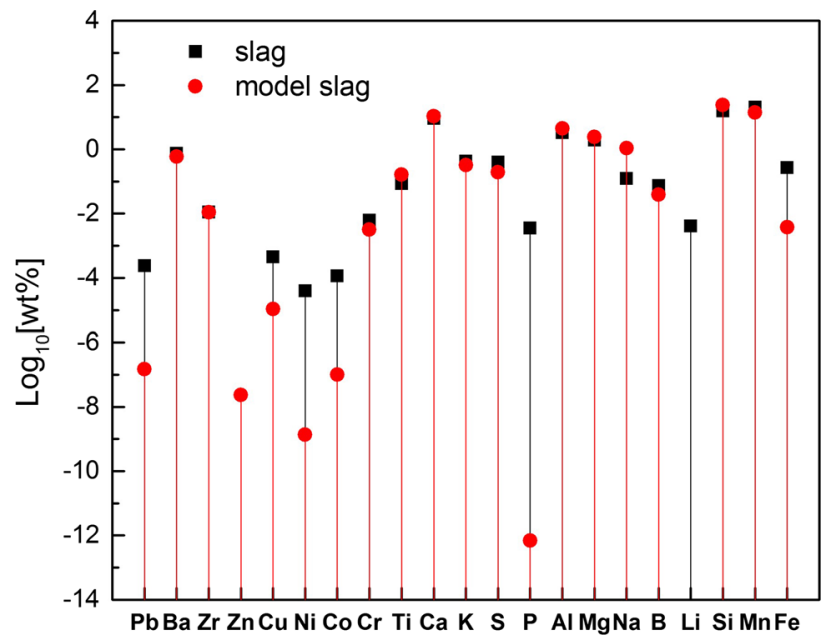

Fig. 16-Comparison of modeled and experimental concentrations of 21 elements in the SiMn slag. Note the logarithmic $y$-axis.

$\mathrm{Mn}, \mathrm{Si}, \mathrm{Fe}$ ) of the metal and slag phases, the agreement between most of experimentally measured and modeled results is good. Nonetheless, further assessment and re-optimization of the metallic binary systems $\mathrm{Si}-\mathrm{Ba}$, $\mathrm{Si}-\mathrm{Na}, \mathrm{Mn}-\mathrm{Na}$, and the ternary systems Si-Mn-X $(\mathrm{X}=\mathrm{B}, \mathrm{Na}, \mathrm{Mg}, \mathrm{Al}, \mathrm{S}, \mathrm{K}, \mathrm{Ca}, \mathrm{Ti}, \mathrm{Zn}, \mathrm{Zr}$, and $\mathrm{Ba})$ are suggested. The binary and ternary interaction coefficients between the slag major oxide components $\left(\mathrm{MnO}\right.$ and $\left.\mathrm{SiO}_{2}\right)$ and minor oxide components $\left(\mathrm{Li}_{2} \mathrm{O}\right.$, $\mathrm{FeO}, \mathrm{CoO}, \mathrm{NiO}, \mathrm{CuO}, \mathrm{ZnO}$, and $\mathrm{PbO}$ ) also need further evaluation and optimization in order to better model the SiMn alloy production system.

\section{CONCLUSIONS}

The minor and trace element distribution throughout the electric arc furnace production process for a $\mathrm{SiMn}$ alloy was established through a pilot scale furnace production campaign. The mass flows of raw materials coke, FeMn slag, Mn ore, and quartz into the furnace, and the mass flows of the SiMn alloy, slag, and fume/gas out of the furnace, were considered.

The distribution of elements between the product condensed phases (metal and slag) and dust is generally in good accordance with the boiling point model. The distribution of elements between metal and slag mainly follows the Gibbs energies of oxidation of the elements. 
1. Most of the alkali metals originate from Mn ore and FeMn slag, and then redistribute to the slag and dust after the reduction process. They are also present in very small concentrations in the metal. The distribution of alkali metals between slag and dust is affected by the competition between their low boiling points and relatively low Gibbs energies of oxidation.

2. Base and transition metals mainly enter the furnace with the FeMn slag, and redistribute to the SiMn metal, slag, and dust. Behavior of most elements is in good accordance with the boiling point model and Gibbs energy of oxidation, except $\mathrm{Ti}$ and $\mathrm{Ta}$ exhibiting non-ideal behavior in both $\mathrm{Si}$ and $\mathrm{Mn}$.

3. In the toxic metals group, $\mathrm{Pb}$ and $\mathrm{As}$ mainly comes from the $\mathrm{Mn}$ ore, with $\mathrm{Pb}$ mainly reporting to dust due to its low boiling temperature, while As reports to both metal and dust due to its high vapor pressure and negative deviation from ideality in both $\mathrm{Si}$ and Mn. Chromium mainly stems from the quartz and Co mainly from the Mn ore and FeMn slag, while they both mainly go to the metal product phase.

4. Among non-metals, B and S mainly originate from the FeMn slag, while $\mathrm{P}$ originates from coke and $\mathrm{Mn}$ ore. Phosphorous mainly goes to the metal phase with a small proportion reporting to the dust phase, which is due to its negative deviation from ideality in both $\mathrm{Si}$ and $\mathrm{Mn}$, and its high vapor pressure. Sulfur behaves as expected and reports mainly to the dust, while $\mathrm{B}$ forms the stable oxide $\mathrm{B}_{2} \mathrm{O}_{3}$ and ends up in the slag.

5. Most of the lanthanide and actinide metals enter the furnace with the FeMn slag, and exits with the slag, due to their low Gibbs energies of oxidation.

Thermochemical simulations were performed for 21 elements using the thermochemical software FactSage 7.1. The agreement between most of the experimentally measured and modeled major components in the three phases is fair. The discrepancies reveal that more accurate thermodynamic descriptions for minor and trace components in such multiphase, multicomponent system are needed to better model the production process.

\section{ACKNOWLEDGMENTS}

Funding from the Norwegian Ferroalloys Research Association (FFF), Saint Gobain, Washington Mills and the Norwegian Research Council through the DeMaskUs project (Contract 245216) is gratefully acknowledged. This publication has also been partly funded by SFI Metal Production, an 8-year Research Centre under the SFI-scheme (Centres for Research-based Innovation, 237738). The authors gratefully acknowledge the financial support from the Research Council of Norway and the partners of SFI Metal Production.

\section{OPEN ACCESS}

This article is distributed under the terms of the Creative Commons Attribution 4.0 International License (http://creativecommons.org/licenses/by/4.0/), which permits unrestricted use, distribution, and reproduction in any medium, provided you give appropriate credit to the original author(s) and the source, provide a link to the Creative Commons license, and indicate if changes were made.

\section{APPENDIX I TAPPED ALLOY COMPOSITIONS ${ }^{|22|}$}

\begin{tabular}{lccc}
\hline & \multicolumn{3}{c}{ Metal Analysis } \\
\cline { 2 - 4 } Tap No. & $\mathrm{Mn}$ & $\mathrm{Fe}$ & $\mathrm{Si}$ \\
\hline 1 & 67.1 & 25.7 & 0.3 \\
2 & 68.9 & 23.7 & 2.6 \\
3 & 67.7 & 19.2 & 9.1 \\
4 & 68.0 & 16.9 & 11.7 \\
5 & 67.6 & 16.0 & 13.3 \\
6 & 67.3 & 16.3 & 13.3 \\
7 & 67.7 & 18.2 & 10.9 \\
8 & 67.8 & 17.6 & 11.2 \\
9 & 66.1 & 18.5 & 12.0 \\
10 & 67.5 & 17.0 & 12.4 \\
11 & 66.8 & 16.9 & 13.1 \\
12 & 67.1 & 15.7 & 10.9 \\
\hline
\end{tabular}

\section{REFERENCES}

1. S.E. Olsen, M. Tangstad, and T. Lindstad: Production of Manganese Ferroalloys. (Trondheim, 2007).

2. M. Tangstad: Metal Production in Norway. (2013).

3. E.H. Myrhaug, and H. Tveit: in 58 th Electric Furnace Conference and 17 th Process Technology Conference, (2000), pp. 591-604.

4. M.K. Næss, I. Kero, G. Tranell, K. Tang, and H. Tveit: JOM, 2013, vol. 66, pp. 2343-54.

5. M.K. Næss, I. Kero, and G. Tranell: JOM, 2013, vol. 65, pp. $997-$ 1006.

6. Y. Ma, I. Kero, S.J.F. Gates, and G. Tranell: in 8th International Symposium on High-Temperature Metallurgical Processing, Springer: Cham, 2017, pp. 215-24.

7. S.E. Olsen, and M. Tangstad: in Tenth International Ferroalloys Congress INFACON X: 'Transformation through Technology', Cape Town, South Africa, 2004, pp. 231-38.

8. R. Shen, G. Zhang, M. Dell'Amico, P. Brown, and O. Ostrovski: ISIJ Int., 2005, vol. 45, pp. 1248-54.

9. I. Kero, M.K. Naess, and G. Tranell: J. Occup. Environ. Hyg., 2015, vol. 12 , pp. 37-44.

10. B. Ravary, L. Hunsbedt, and O. Kristensen: in The thirteenth International Ferroalloys Congress Efficient technologies in ferroalloy industry, Almaty, Kazakhstan, 2013, pp. 1023-28.

11. S. Gaal, M. Tangstad, B. Ravary, and E. Ringdalen: in $X X V$ International Mineral Processing Congress-IMPC 2010, Brisbane, Australia, 2010, pp. 3743-50.

12. S.Gaal, M. Tangstad, and B. Ravary: in The Twelfth International Ferroalloys Congress Sustainable Future, Helsinki, Finland, 2010, pp. 81-88. 
13. F.W. Noble, B.A. Senior, and B.L. Eyre: Acta Metall. Mater., 1990, vol. 38, pp. 709-17.

14. R.S. Hyde, G. Krauss, and D.K. Matlock: Metall. Mater. Trans. A, 1994, vol. 25A, pp. 1229-40.

15. N. Yoshida, O. Umezawa, and K. Nagai: ISIJ Int., 2003, vol. 43, pp. $348-57$.

16. M.B.D. Haaland, and T. Thomassen: in Infacon IX-The Ninth International Ferroalloys Congress, Quebec City, Canada, 2001, p. 8.

17. Factsage, http://www.factsage.com/ 2017.
18. S.C. Rencken: University of Pretoria, 2013.

19. S. Bao: in Department of Materials Science and Engineering, Norwegian University of Science and Technology: Trondheim, 2011.

20. N. Kvitastein: in Department of Material Science and Engineering, Norwegian University of Science and Technology: Trondheim, 2016.

21. I.H. Jung and Y. Zhang: JOM, 2012, vol. 64, pp. 973-81.

22. E. Ringdalen and I. Solheim: in Infacon $X V$ : International Ferro-Alloys Congress, Cape Town, 2018. 